\title{
Government and Community Involvement in Environmental Protection and Flood Risk Management: Lessons from Keko Machungwa, Dar es Salaam, Tanzania
}

\author{
Tumpale Sakijege ${ }^{1}$, Junun Sartohadi' ${ }^{1}$ Muh Aris Marfai' ${ }^{1}$, Gabriel Kassenga², \\ Samson Kasala ${ }^{3}$ \\ ${ }^{1}$ Faculty of Geography, Gadjah Mada University, Yogyakarta, Indonesia \\ ${ }^{2}$ Department of Environmental Science and Management, Ardhi University, Dar es Salaam, Tanzania \\ ${ }^{3}$ Department of Urban and Regional Planning, Ardhi University, Dar es Salaam, Tanzania \\ Email: tumpaleg@yahoo.com
}

Received 15 April 2014; revised 13 May 2014; accepted 3 June 2014

Copyright (C) 2014 by authors and Scientific Research Publishing Inc.

This work is licensed under the Creative Commons Attribution International License (CC BY). http://creativecommons.org/licenses/by/4.0/

(c) (i) Open Access

\section{Abstract}

Since the 1960s, most cities in developing countries have faced a high rate of urbanization, which in turn has caused more harm to low-income earners, in urban areas. A majority of low-income earners most often face difficulties in accessing land in planned areas, as a result they are forced to build houses in unplanned settlements that are vulnerable to natural hazards. The situation is worse to the extent that people encroach the most vulnerable areas (hazard lands). As concentration of people increases, these unplanned areas become more unsafe to live in. This is partly due to the risks associated with natural hazards particularly flooding. Further, vulnerability of unplanned settlements in developing countries is aggravated by hosts of problems caused by many factors, including inadequate Government involvement in: environmental protection especially managing hazard lands and helping the community to minimize risks associated with hazards. This paper addresses this issue. It argues that community and Government initiatives are vital to any strategy for flood risk reduction and environmental protection in general. The study employed both the primary and the secondary data sources. Data collection tools and techniques involved in this study included: Checklist to various leaders, interview using questionnaires, focus group discussion, analysis of aerial photographs and non participant observation. A total of 70 households from within Keko Machungwa were interviewed. The study revealed that flooding is largely contributed by construction done by a large scale developer on a water course; and when affected community initiated a strategy to solve the problem they partially succeed due to inadequate support from the Government and other stakeholders. These findings could be useful to strengthen policy and legislation in environmental protection, management and flood control as well as in 
intervening land use conflicts between local community and developers.

Keywords

Environmental Protection, Community, Government, Flood Risks, Keko Machungwa

\section{Introduction}

Globally it has been noted that each day about 193,107 new urban dwellers are added to the world's urban population [1]. The world urban population is expected to increase for the next decades [2], OECD (2011) projected that by 2050 the world urban population will reach 70\% of the world population [3]. Moreover, the bulks of these new urbanites are poor and therefore are not able to meet their accommodation and service needs through formal mechanisms [1]. Unfriendly forms of urbanization, which in most cases are not in favor of the low income earners, led the majorities of the poor people to be pushed into locations that are not protected environmentally (Figure 1) and hence they are prone to natural hazards in general and flood in particular [4].

The above urbanization challenges were expected to be tackled by Government through urban planning and environmental protection [5]. Galea and Vlahov (2005) and Kochtitzky et al. (2006) note that, urban planning and environmental protection are supposed to ensure that the community's requirements such as housing, healthcare infrastructure, water supply, natural resource utilization, accessibility and good living condition are available in sufficient levels to meet the rapidly changing urban population [5] [6]. The situation however is different; many countries around the world mainly from the developing world lack proper urban planning, environmental protection policies and implementation mechanism. The existing proper urban plans and environmental protection policies are not implemented satisfactorily [1] [7]-[9]. This argument is also supported by the Secretary- General United Nations, His Excellency Ban Ki-moon who said;

Evidence from around the world suggests that contemporary urban planning has largely failed... Urban sprawl and unplanned per urban development are among the most visible consequences, along with the increasing vulnerability of hundreds of million [1].

As argued above, poor planning and improper Government involvement in protecting the environment and managing its available land is known to be the major cause for the growth of unplanned settlements. Growth of unplanned settlements is a major factor in the increase of floods [10] [11]. This is reaffirmed by Parker (1999) and WMO/GWP (2008) who noted that urbanization worsens floods by diminishing the permeability of ground surfaces and increasing runoff rates [12] [13]. Mostly, regulations, rules and procedures are imposed among others for the intention of protecting the environment and avoiding disasters. To cite an example, Tanzania has master plans for different cities; the Dar es Salaam City Master Plan of 1968 designated all the wetlands area as “hazard lands”. Significant example include: Msasani Bonde la Mpunga [14], Keko Machungwa Bondeni [15]. These lands were considered hazard lands because they were waterlogged throughout the year and hence not suitable for human settlements development. Surprisingly, since 1979 residents started to elect residential buildings informally. Further to that, during mid 1980s, people continued to change the hazard land very rapidly to a

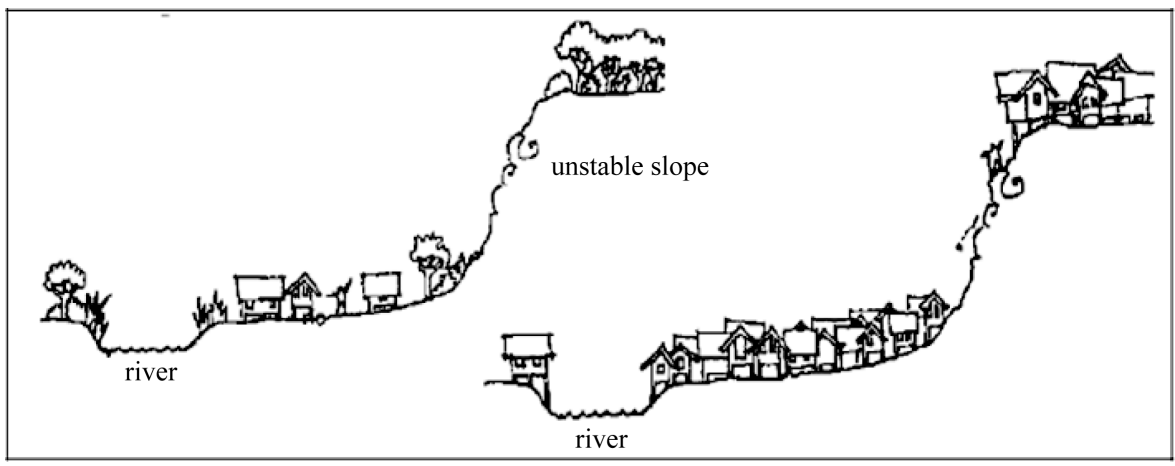

Figure 1. Settlement in risky sites/areas [4]. 
residential-commercial housing area [14]. It is important to note that these changes involved planning authorities [14] [15]. In other words, the owners of commercial buildings were and are still being given building permits to develop in these areas. The development practices increased the risk of flooding in those areas. It is argued so because buildings obstruct the main drainage channel which used to discharge storm water within the wetland. Because the Government is responsible for managing its arable and hazard land, it is important to understand the involvement of the Government and the community in environmental protection and minimizing flood risks in unplanned settlement. The main objective of the current study is to explore involvement of the Government in supporting community efforts in environmental protection and flood risk minimization. Specifically the study aims to: document the causes and risks associated with flooding; analyze the extent of flooding; explore community coping strategies in managing flooding and explore the cooperation between Government and local community in protecting the environment and managing flooding.

\section{Methodology}

Case study strategy was used whereby Keko Machungwa informal settlement in Dar es Salaam city was selected as a suitable case study area. Keko Machungwa was selected based on its richness in information to address the research problem. Furthermore, selection of Keko Machungwa was guided by the fact that it is an informal settlement which is frequently affected by flooding, and local community employed different adaptation strategies to minimize flood associated risks. The sampling techniques employed in this study included both probability and non probability sampling. On one hand, purposive sampling design was employed because the power of purposive sampling lies on selecting information-rich cases for in-depth studies [16]. Therefore areas which were affected by floods whenever it rains were chosen.

\subsection{Description of the Study Area and Magnitude of Flooding}

The study was carried out in Keko Machungwa sub-ward. Keko Machungwa is an unplanned settlement which is situated about 3 kilometers from the Dar es Salaam City centre. The settlement lies between latitude 6 $6^{\circ} 0^{\prime} 10^{\prime \prime}$ and $6^{\circ} 50^{\prime} 41^{\prime \prime}$ South and between longitude $39^{\circ} 16^{\prime} 35^{\prime \prime}$ and 36 $16^{\prime} 11^{\prime \prime}$ East. Keko Machungwa is located in a low lying terrain (Figure 2), it is therefore within the river valley and thus susceptible to flooding. The valley was a wetland and previously was used for farming. In addition, the valley is a river course which receives surface runoff from upper part of the settlements and drain to the Indian Ocean. According to the Dar es Salaam Master Plan of 1968, part of the settlement (Keko Machungwa valley) was earmarked as hazard land and thus it was considered not suitable for human settlement development. Currently, the settlement is used for residential and commercial purposes, this practice influenced the problem of flooding. The problem of flooding is attributed by increased number of houses and encroachment to the river valley. The problem of flooding escalated in 2000's and the situation started to be worse in 2005. Against that background, Keko Machungwa settlement was therefore chosen for exploring Government and community involvement in minimizing flood risks and protecting the environment.

\subsection{Sample Size Selection}

The study involved a sample size of 70 households. The sample size was determined using a mathematical formula specified in Baradyana and Ame (2005) [17]. After establishing the sample size for interview, simple random sampling techniques were applied to select the 70 respondents.

\subsection{Data Collection Methods}

Documentary review, interview, focus group discussion and analysis of aerial photograph were used for data collection in this study. Interview was the main tool of data collection methods applied; it involved household interview and official interview. A total of 70 household were interviewed, the interviewer was guided by a structured questionnaire. Another interview involved officials from Keko Machungwa sub-ward and Temeke Municipal Council, this method availed information on the study. Analysis of aerial photographs was the major sources of spatial data in this study, aerial photograph for two different years (i.e. 2005 and 2012) were analyzed to depict dynamics of encroachment to the valley. Other data collection tools were focus group discussion and physical observation. 


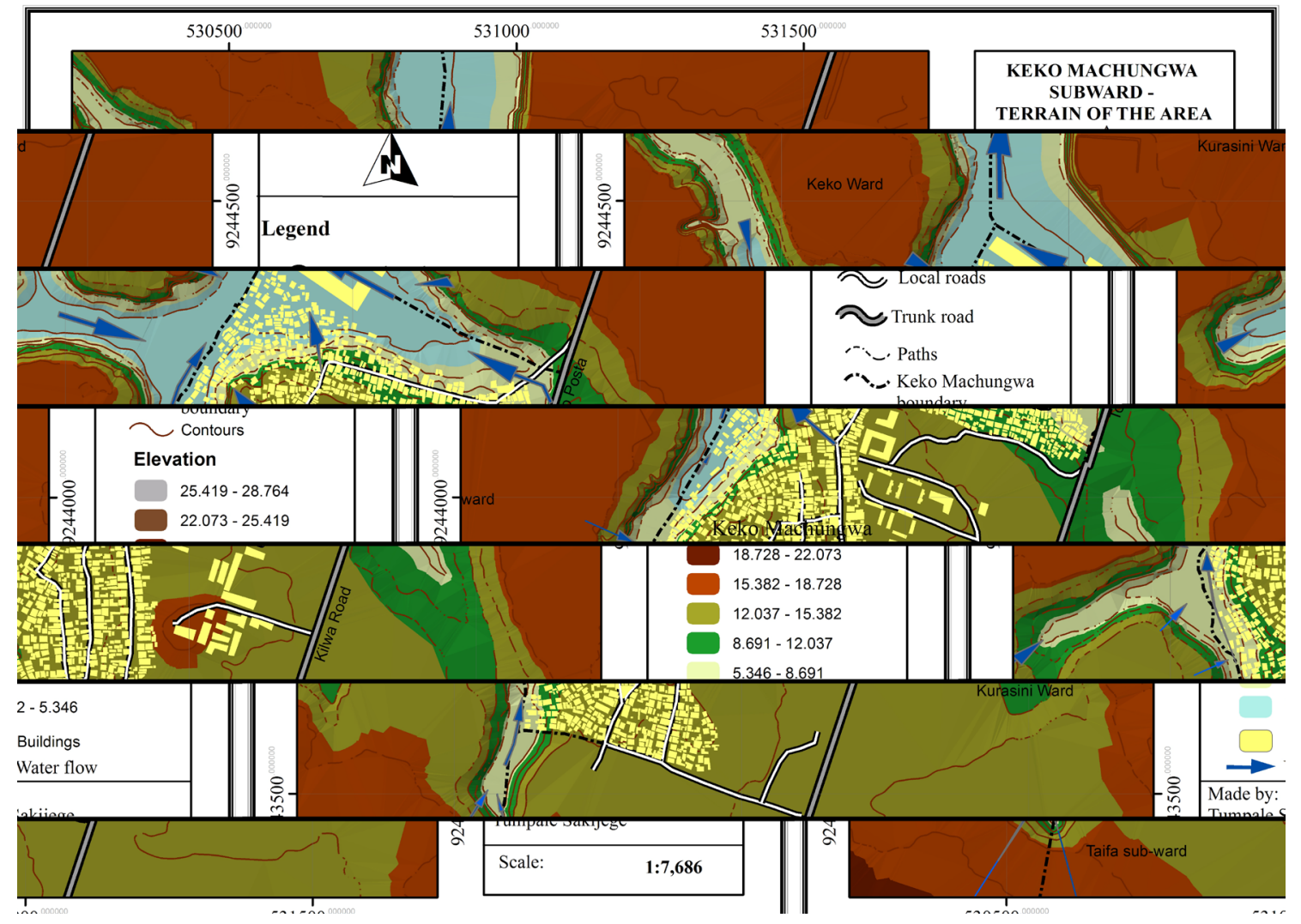

Figure 2. River valley of Keko Machungwa.

\section{Results and Discussion}

\subsection{Causes of Flooding}

Based on the analysis of interview made, causes of flooding in Keko Machungwa include: encroachment of the river valley, housing densification, inadequate storm and wastewater drainage system and blockage of drainage channels due to haphazard dumping of solid waste (Figure 3).

It is apparent from Figure 3, encroachment of the river valley was reported by a large percent of the respondent (52\%), followed by housing densification (21\%), lack of storm and waste water drainage system (17\%) and lastly haphazard dumping of solid waste (10\%). This study focused on the encroachment of the river valley because during physical observation authors noted that a permanent wall and warehouses were built in a large part of the valley. As a result during rainfall large amount of surface runoff get blocked by the wall and diverted to residential premises. This situation causes flooding in the settlement. At the same time, the authors observed that land in the area where the wall and warehouses have been constructed was reclaimed by ways of cut and fill from the river valley. The land is relatively elevated than the other land on which the rest of the settlement exists. The practice of reclaiming land, and constructing in a river valley, as the situation is in Keko Machungwa, has been aggravating flooding in the rest of the settlement. This observation also confirms with views of $52 \%$ of interviewed respondents. It was found that a large scale developer started to reclaim part of the valley in 2000. This is when the problem of flooding started to attract attention of the media, environmental and health experts. The reclamation of land necessitated shifting the river course from its original natural path towards adjacent residential areas. The problem persisted after the company constructed a wall on the reclaimed land. Looking annoyed, one of the ten cell leaders whose house is within the area affected by flooding expressed that:

The flooding condition is very bad, largely caused by the wall built by the large scale developer, consequently storm water from upper parts of this settlement is blocked by the wall and come back to our houses. We live like fish, frankly speaking the situation was not like this before.

The complains by residents about the wall constructed by the large scale developer is a testimony of how the 


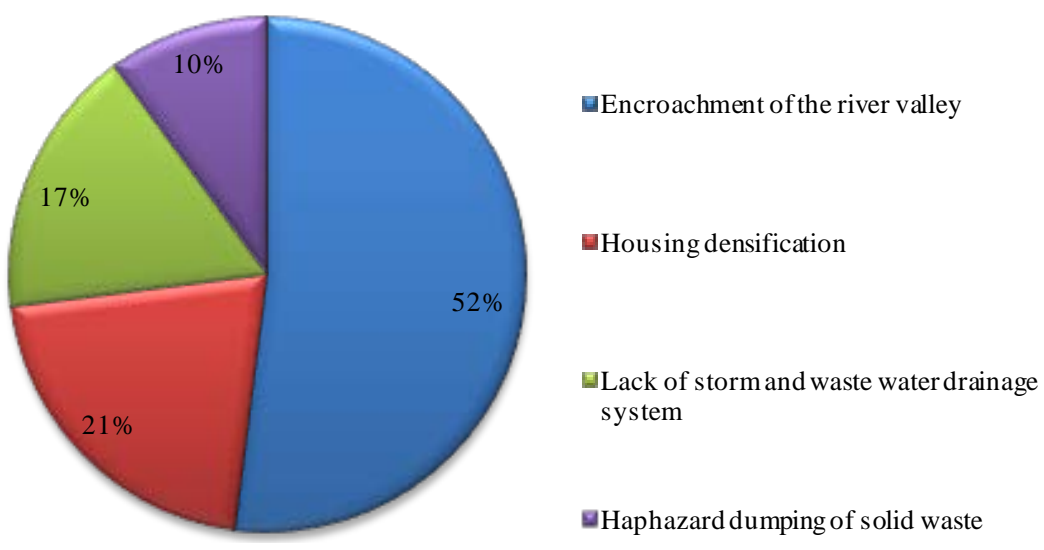

Figure 3. Causes of flooding.

local people understand their environment and how certain developments affect their lives. Similarly, the explanations above is in line with perception of respondents (52\% reported that encroachment done by the large scale developer is a major causes of flooding in the settlement), observation made in the field (see Figure 4) and the real situation of the settlement as seen in the satellite images (Figure 5 and Figure 6). Figure 5 and Figure 6 show the way the large scale developer reclaimed large part of the valley and put construction. It was reported by the Chairman of Keko Machungwa sub-ward, Temeke Municipal engineer and the member of the focus group discussion that, the large scale developer has a valid building permit. This means that, by granting building permits to developers the relevant local authority entrusted to protect the environment contributed to the problems of flooding, this practice in other words is a constrain in environmental protection particularly managing the hazard lands by local authorities.

\subsection{Risks Associated with Flooding}

Flood related risk is the probability of harmful consequences, or expected losses resulting from interactions between rainfall as a natural phenomena and vulnerable conditions in a particular area. By means of household questionnaire, observation, official interview and focus group discussion, flood effects and damages have been systematically analyzed. Figure 7 illustrates respondent responses on the effects of flooding.

$39 \%$ of the respondents reported diseases as one of the risks associated with floods, diseases that were reported include: Malaria, Urinary Track Infection (UTI), Diarrhea, Schistosomiasis, Typhoid and Fungal. Quick assessment shows that reported diseases have been found to be water-borne in nature. The problem of water logging and blocked accessibility is worse in the area which is within the valley. Houses in this area stay waterlogged for a period of between 3 to 12 months. This situation makes such houses inhabitable and prevents owners from using their houses for that period. Technically, this problem is referred to as groundwater flooding [18]. Foster et al. (2002) reported that groundwater flooding is most likely to be a problem in areas that are low-lying [18], this is the case in Keko Machungwa (Figure 2). Further, it was revealed that in Keko Machungwa both buildings and properties are affected by flooding. Destruction of properties as one of the effects of floods was reported by $17 \%$ of the respondents.

\subsection{Extent of Flooding}

A topographic analysis of the settlement showed that a total of 6 hectares is affected by flooding. Compared to the total land area of Keko Machungwa (30.95 hectares), the area affected by flooding is equivalent to $19 \%$ of the total land area. Flood coverage has increased by 0.93 hectares (equivalent to 3\%) from 5.03 hectares in 2009 (Flood coverage in 2009 according to the study done by Sakijege et al. (2012) [15]. Implying that if immediate actions are not taken, flood coverage will continue to increase. One of the respondents reported that:

I constructed my house in 1986, during that time there was no flooding problem at all, we started experiencing flooding in 2000 after one of the developer bought part of the wetland, filled it with gravel and constructed a security wall and warehouses. He added that, the number of houses affected by flooding is increasing, as we are talking, about 150 of houses are affected by flooding including mine. 


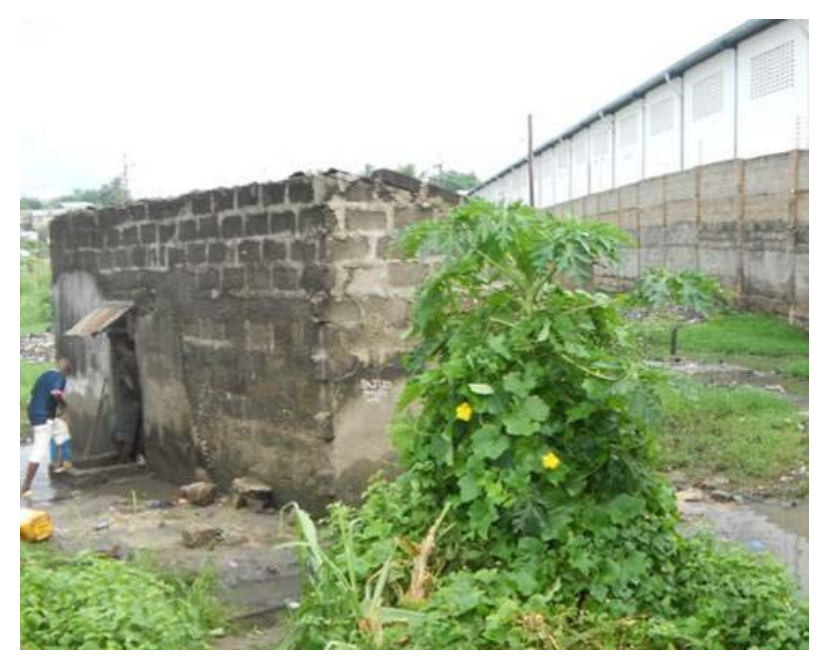

Figure 4. Wall and a warehouse constructed on the reclaimed land, during flood this area is filled with surface runoff.

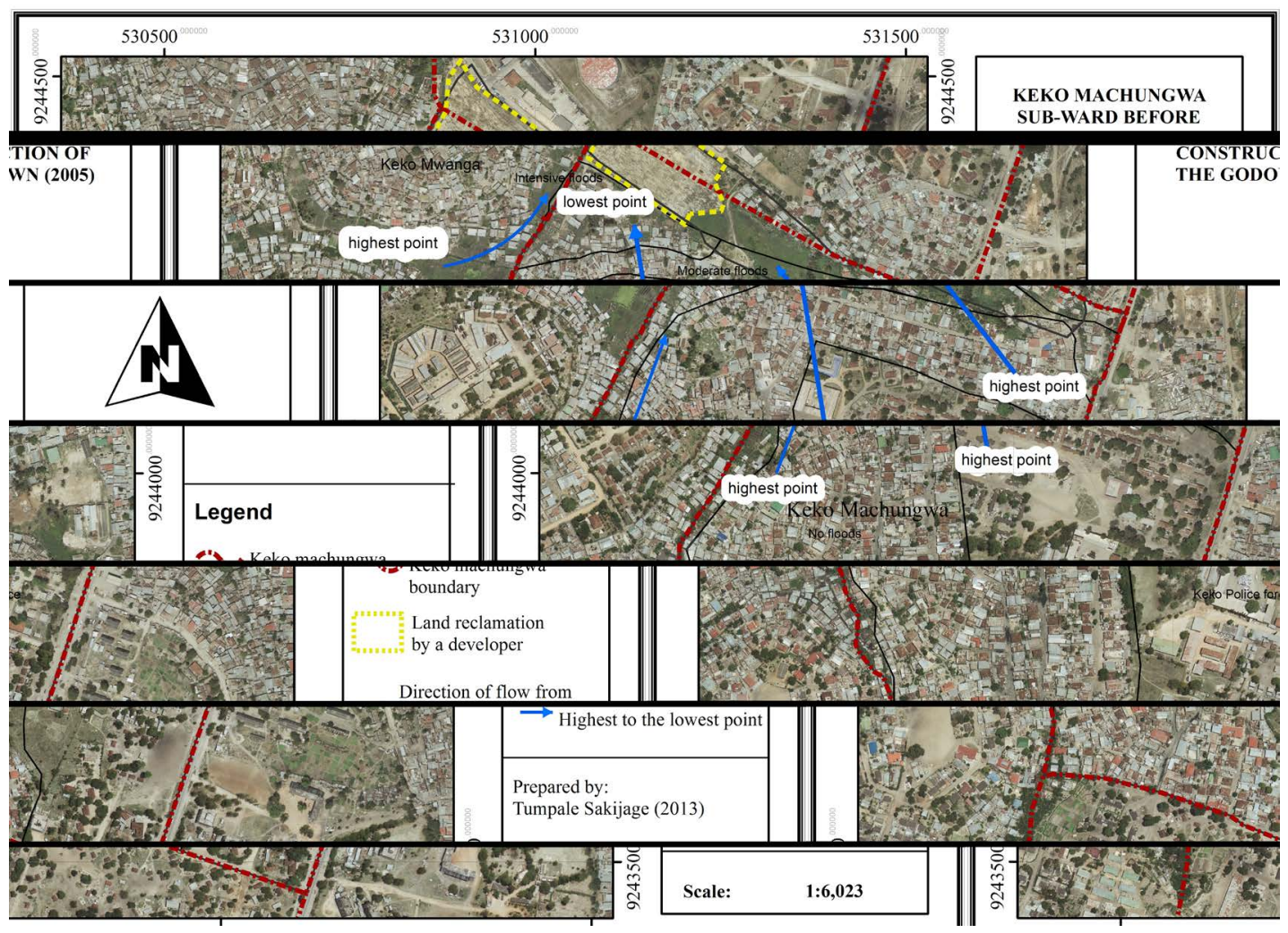

Figure 5. Satellite image of Keko Machungwa before construction of the warehouses (in 2005).

The statement above depicts causes of flooding and flood coverage in terms of number of houses affected in relation to the previous situation. In a discussion with the Chairman of Keko Machungwa sub ward, it was confirmed that a total number of 150 houses are severely affected by flooding. This figure is similar to the one reported by one of the respondents as highlighted above. However, the chairman claimed that the 150 houses are affected by flooding because of haphazard housing development in water course areas. He further noted that during property formalization ${ }^{1}$ program a large number of houses in Keko Machungwa (along the valley) were

${ }^{1}$ Property formalization refers to the process of transforming properties from informal system which is not legally recognized to formal system which is legally recognized in a modern market-based economic system. 


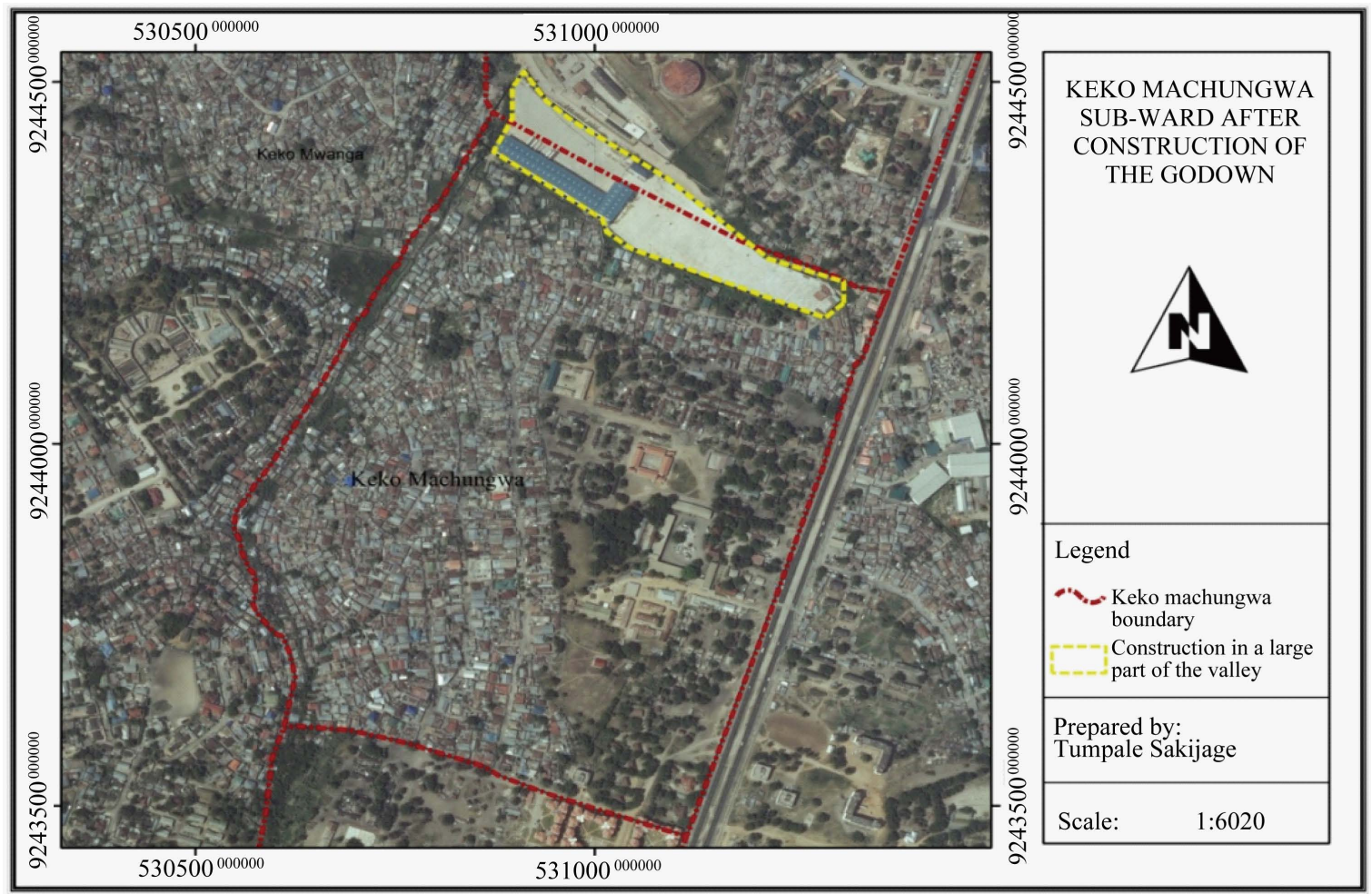

Figure 6. Satellite image of Keko Machungwa after construction of the warehouses (in 2012).

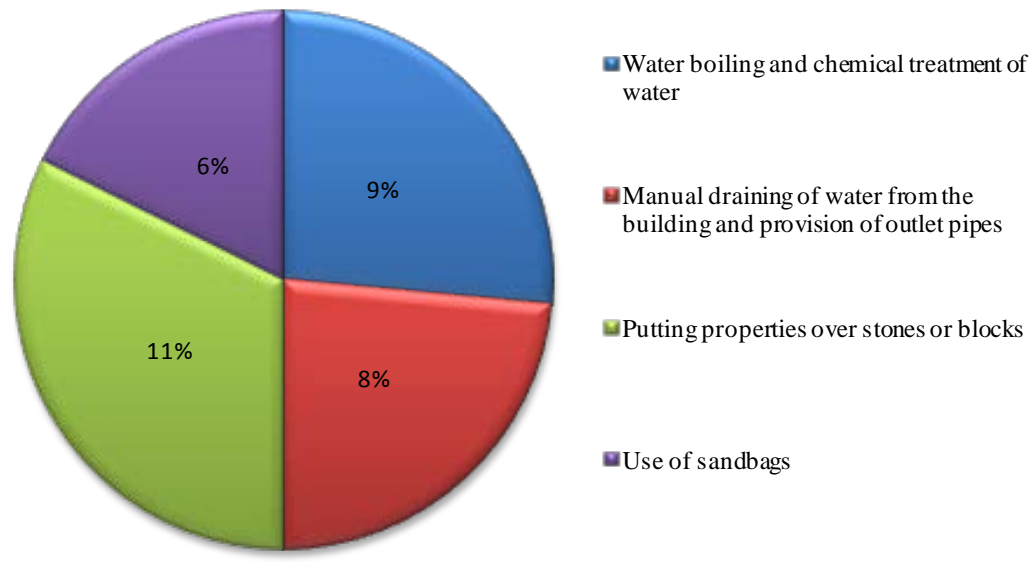

Figure 7. Effects of flooding.

not formalized, instead they were earmarked as houses in hazardous land and thus did not qualify for formalization. The study done in 2009 by Sakijege et al. (2012) [15] reported that about 84 houses were severely affected by floods. It is noticeable that between 2009 and 2013 the extent of flooding in terms of the number of houses affected has increased by 76\% (an increase of 64 houses). Figure 8 illustrates extent (flood zones) of flooding and affected houses in Keko Machungwa settlement.

\subsection{Community Coping Strategies in Managing Floods}

Several adaptation strategies have been initiated to minimize flood hazard. At household level depending on individual coping capacity the adaptation strategies include: construction of protective wall around the houses (23\%), raising house foundation (19\%), raised pit latrines (16\%), putting household items over stones or blocks (11\%), temporarily shifting to other alternative places (8\%), use of sandbags (6\%) and many others (17\%). This 


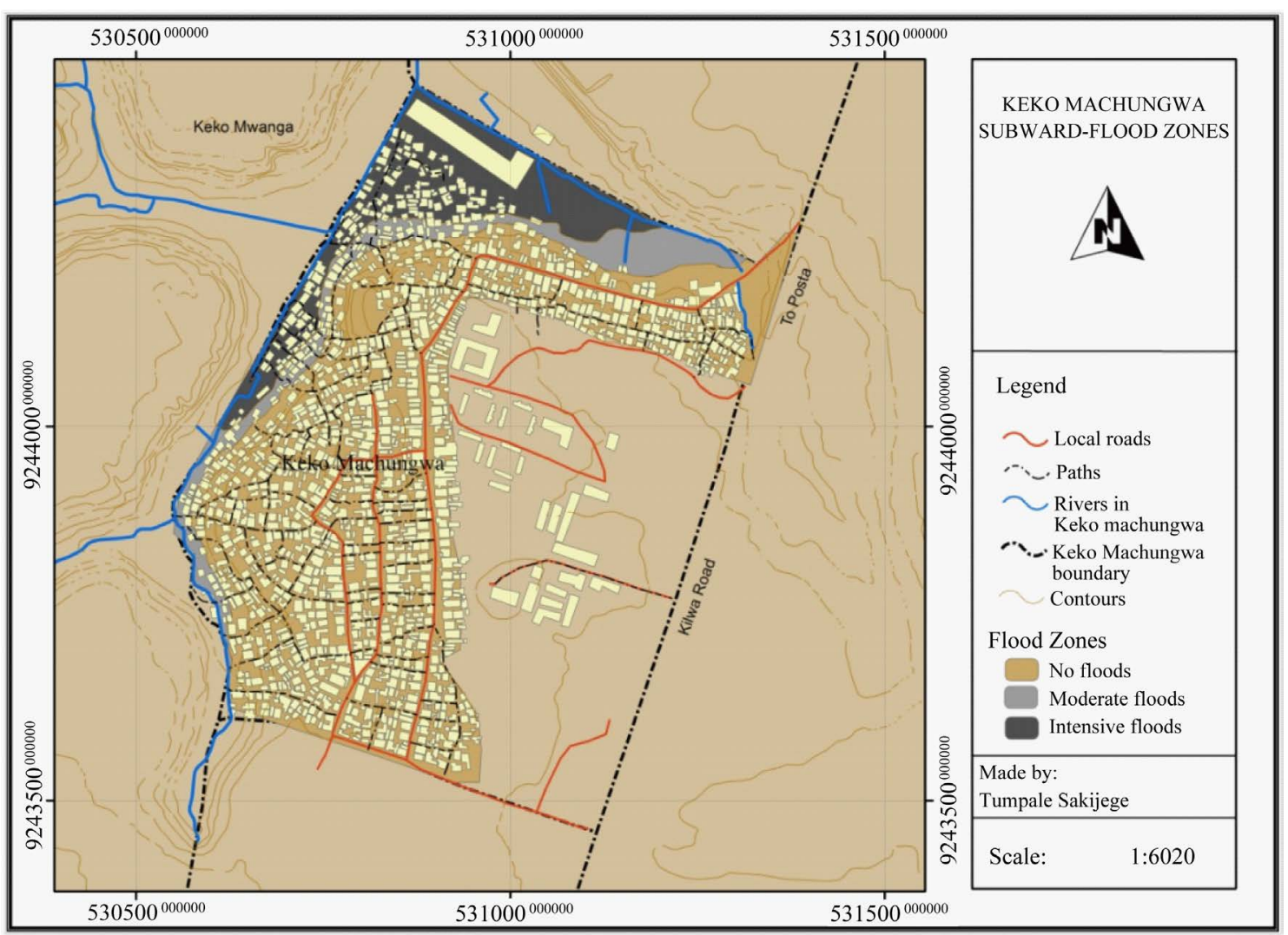

Figure 8. Flood zones, coverage and affected houses.

study found that most of these adaptation strategies are vulnerable to flooding because they were devised with little consideration on the technical standards. Adaptation strategies at the community level include: compensating and relocating flood victims, upgrading access road, improving solid waste management services, construction of foot bridges, facilitating construction of household and public toilets. In the course of conducting this study, it was found that the strategy of compensating and relocating flood victims is given priority than other strategies as it was reported by $88.5 \%$ of the respondents. This is justified by the perception of the people as regards to the causes of flooding. Encroachment of river valley for warehouse construction is one of the main causes of flood reported by residents in Keko Machungwa. In view of this, residents in Keko Machungwa in collaboration with the sub-ward office constituted a committee whose main task was to urge the Municipal Council to stop haphazard development along the valley. This was by requesting the large scale developer who had blocked the river to demolish some sections of the walls and warehouses and through Municipal Council to urge the large scale developer to compensate damages caused by flooding. The initiatives outlined above started in 2000 and are similar to those reported by Sakijege et al. (2012) [15]. According to Sakijege et al. (2012), by the time the study was conducted (in 2009), the community initiative were not fruitful [15].

It was found that, community initiative for flood risk solutions continued, the community through their committee continued to make follow-ups to different authorities including the President of the United Republic of Tanzania (URT). Part of a letter that was written to the President of the URT reads as follows in English language:

Re: Complains against director of the Oil Com Company Ltd. (a developer who bought of the houses within valley in Keko Machungwa, Temeke). Currently he continues to construct a wall and blocks the drainage channel supposed to pass inside his area, forcing the channel to pass to the residential houses and causes flooding. Despite orders from the Minister for Lands, Housing and Human Settlements to Temeke District Commissioner to intervene and solve the problem, nothing has been done.

Efforts by the community in general and the committee in particular were successful in bringing to the attention of the authorities the magnitude of the problem. It was also successful in terms of partially reducing flood 
risks affecting residents. This was a result of the developer accepting to compensate flood victims by a way of buying areas and houses owned by them. Property valuation conducted by a developer identified a total number of 39 households that were entitled for compensation. The large scale developer was given a maximum of six months to finish compensating flood victims. However, it has been revealed that as of June 2013 when the study was conducted, a total of only 20 households were paid compensation, the rest (19) flood victims were still waiting. The amount paid ranges between 25,000,000 (USD 15,347) - 40,000,000 (USD 24,555) ${ }^{2}$ million per house. Comparing with the number of houses (150 houses) affected by flooding as revealed by the study and the 39 houses entitled for compensation, 111 houses were left out. Similarly, during the focus group discussion one of the residents pointed out that:

I was surprised to see names of my neighbors in the list of flood victims entitled to compensation. We are all facing similar problems but our house was not included. I fail to understand the criteria used to select 39 houses.

From discussion it can be observed that the community was not satisfied with the compensation exercise. More specifically, valuation task was conducted by the large scale developer while in reality the Government through Temeke Municipal authority was supposed to oversee the exercise. In view of this, it could be one of the reasons that led to the delay of compensation of the remaining 19 households. Although the large scale developer is largely responsible for compensating flood victims as opposed to the Government, they might be doing so for their own benefit. In this case, it was interesting to know the alternative use of the area after compensation and relocation of the current occupiers. In an interview with the chairman of the sub-ward, it was revealed that the large scale developer agreed to compensate flood victims on humanitarian grounds, and that the company has no interest in developing the land. However, the reality on the site shows that, the large scale developer would be attracted to expand his warehouse yard to cover the areas where current occupiers are being compensated to leave.

The practice shown by the community in Keko Machungwa, that is to convince the Government to stop encroachment done to the valley, is a testimony of the way the community participates in environmental protection for the benefit of both the natural environment and humans. Due to the pressures of population and buildings (particularly warehouses on the river course), the natural environment is being degraded to the extent of escalating flooding problems which was not previously experienced.

\subsection{Cooperation between Government and Local Community in Managing Floods}

As argued by the respondents, Chairman of Keko Machungwa sub-ward, and considering the local context, potentially, settlement vulnerability has been observed to increase. The illegal practice of construction on the water-course blocks surface runoff, resulting into severe flooding to the residents. The situation will be worse if immediate actions are not taken. Community in Keko Machungwa is aware of these issues and community members expressed their willingness to protect their environment and minimize flooding through requesting the Government to intervene. The efforts of people in their struggle to cope with flooding situations, has inclined Governments to assist communities in Keko Machungwa in addressing flood issues. The Government's assistance has involved mediating on the existing land use conflict related to blockage of a river course. Mediation has involved ordering the large scale developer whose wall has blocked a river course to facilitate resettlement by paying compensation to flood victims. This approach on the one hand was an achievement. However, the approach caused some problems, in a sense that flood victims were not satisfied with both compensation values and the number of those entitled for compensation. According to a property valuation exercise conducted by the developer a total number of 39 households entitled for compensation were identified. Comparing the number of 150 houses affected by flooding, as revealed by the study and the 39 houses entitled for compensation as it was established by the developer, there is a difference of 111 houses. Likewise, the developer was given a maximum of six months to finish compensating 39 flood victims. However, it has been revealed that as of June 2013 when the study was conducted, a total of 20 household were paid compensation, the rest (19) flood victims were still waiting.

It can be learnt from the findings that, probably corruption may have played part in influencing decisions related to: issuing of a large scale development permit in a river valley on the one hand, and entrusting a developer to handle compensation matters on behalf of a local authority, on the other. The thinking that corruption may

\footnotetext{
${ }^{2} 1$ USD is equivalent to about TShs. 1629as at March 4, 2014, available at http://www.dse.co.tz/
} 
have played part can be clarified by several reasons: (i) It is unethical to allow a large scale developer to construct in a river valley, (ii) The local authority responsible did not oversee the compensation exercise in accordance with relevant laws, that's why (iii) proper procedures were not followed in the valuation exercise as stipulated in Sections 3(G) and 179 of the Land Act No. 4 of 1999, (iv) Members of the local community who were the victims and first responders when flooding occurs were not involved in the process of identifying flood victims entitled to compensation, (v) Institutional mechanisms at lower levels was inadequate in helping the local community to solve their problem. That is why the local community in Keko Machungwa took their complaints to the President of the United Republic of Tanzania. All these are governance issues.

The act of the local Government authority to entrust the developer is not in line with the objectives of the Tanzania National Environmental Policy of 1997 and the Environmental Management Act, 2004. The policy for example, acts as a framework for environmental decision making in Tanzania. One of the policy objectives is to promote individual and community participation to ensure sustainable and equitable use of resources without degrading the environment or risking health or safety. The act of entrusting the developer to determine flood victims entitled to compensation and conduct a property valuation exercise was not only contrary to relevant laws but also denied other stakeholders (particularly the local community) the right to participate in decisionmaking as provided for in the National Environment Policy of 1997 and Environmental Management Act, 2004. At the same time the Land Act No. 4 of 1999 provides, under Sections 3 (G) and 179 the rights and obligations of parties involved in a compensation protocol. According to the Land Act, in the absence of Government intervention, several compensation elements cannot be fairly addressed by either party.

In addition, it is so far not clear as to what will be the alternative use of the area after relocation. The Government is quiet on this, this means that it is for the large scale developer to decide. According to experience and as it is seen in the aerial photograph (Figure 4 and Figure 5) the developer has the practice of expanding its area slowly. It is therefore likely for the developer to expand its construction to cover the vacant area (the area previously owned by the 39 flood victims). In spatial context this means the problem of flooding will increase and shift to other household who were previously not affected. In flood disaster management, issues between those causing flooding, flood victims (local people) and institutions mandated to manage flooding (like the local Government) need to be tackled amicably. Joint efforts between the local Government, local people and other stakeholders could greatly help reach informed decisions in the development of sustainable adaptation strategies for flood minimization and environmental protection in general.

The study by Jabeen et al. 2010 [19] and Haque et al. (2012) [20] argued that (i) most of the settlements in developing countries are prone to flooding due to their location in a risk sites, (ii) Efforts by local dwellers in minimizing impacts of flooding are deterred by a number of factors which include: insufficient funds, threat of eviction and insecurity of land tenure. Jabeen et al. 2010 [19] and Haque et al. (2012) [20] pointed the need for involvement and support for both local and national policy makers regarding selecting flood management measures that meet multiple local objectives. The findings by Jabeen et al. 2010 [19] and Haque et al. (2012) [20] are similar to the finding of this study, the study found the need for involvement of the Government, local community and other stakeholders in any strategy for environmental protection and flood risk reduction in particular.

\section{Conclusions}

The magnitude of flood risk is expected to increase in future as a result of rapid development in the flood-prone areas. Empirically, this study has shown that there is a lack of effective participation between Government and the community as far as flood risk reduction is concerned. The Government which is entrusted to protect the environment, particularly to manage hazard land, is not doing so, as such the use of the hazard land has been changed to commercial and residential uses. These development block surfaces runoff, and the blocked surface runoff ended up inundating surrounding residential areas which consequently increases vulnerability of local people. It was observed that local people who are severely affected by flooding establish adaptation strategies for protecting the environment and flooding impact. However, the strategies failed because of little support from the Government and other stakeholders. The study recommends as follows:

There is a need to strengthen policy and legislation related to environmental protection and flood management. Strengthening flood management and environmental protection policies may also imply increasing efforts to the wise use of the hazard land and minimization of the flood risks.

The problem of flooding was aggravated after the Government allocated land to a large scale developer. In 
allocating land for development, it is important to ensure that compatibility of land uses is considered for minimizing conflicts and flooding.

The study finds that the rights of the flood victims were not full addressed in the ongoing relocation exercise done by the developer. It is therefore important to involve every stakeholder (including the local community) in addressing flood related problems. Collective discussion between all stakeholders will help in reaching sustainable solution especially when the environment and residents in hazard lands are at stake.

Responsible authorities for protecting the environment in Tanzania, which include local authorities, the Land use planning commission, the Ministry of Lands, Housing and Human Settlement Development (MLHHSD), Disaster Management Department in the Prime Minister's Office and the National Environmental and Management Council (NEMC) should work together and ensure that development in hazard land is restricted for minimizing flood risks.

\section{Acknowledgements}

The authors acknowledge and express their gratitude to the Beasiswa Unggulan, Ministry of Education and Culture of Indonesia for the financial support. We also thank W. Kasyegeta (Dar es Salaam American Embassy) and R.Robert (Ardhi University) for their kind support during field survey.

\section{References}

[1] UN-HABITAT (2009) Planning for Sustainable Cities, Global Report on Human Settlements, United Nations Human Settlements Programme. Earthscan, London.

[2] OECD (2006) Competitive Cities in the Global Economy. OECD, Paris.

[3] OECD (2011) Environmental Outlook to 2050, Climate Change Chapter. Pre-Release Version, OECD, Paris.

[4] Marschiavelli, M.I.C. (2008) Vulnerability Assessment and Coping Mechanism Related to Floods in Urban Areas: A Community Based Case Study in Kampung Melayu, Indonesia. MSc. Dissertation, Double Degree Program, University of Gadjah Mada and International Institute for Geo-Information Science and Earth Observation.

[5] Kochtitzky, C.S., Frumkin, H., Rodriguez, R., Dannenberg, A.L., Rayman, J., Rose, K., Gillig, R. and Kanter, T. (2006) Urban Planning and Public Health at CDC. Morbidity and Mortality Weekly Report (Centers for Disease Control and Prevention), 55, 34-38.

[6] Galea, S. and Vlahov, D. (2005) Handbook of Urban Health: Populations, Methods and Practice. Springer, New York. http://dx.doi.org/10.1007/b104167

[7] Kombe, W.J. (1999) Urban Poverty, Service Provision and Land Development in Tanzania: Predicaments and Prospect. Workshop Proceedings, Institute of Engineers of Tanzania (IET), Arusha, Tanzania, 6-27.

[8] Kyessi, A.G. (2002) Community Participation in Urban Infrastructure Provision: Servicing Informal Settlements in Dar es Salaam, Tanzania. Ph.D. Dissertation, Faculty of Spatial Planning, University of Dortmund, Spring Research Series, No. 3, Dortmund.

[9] Kasala, E.S. (2013) Operationalizing Strategic Urban Development Planning: The Case of Dar es Salaam City, Tanzania. Ph.D. Dissertation, University of Dar es Salaam, Tanzania.

[10] Benouar, D. (2002) The Need for an Integrated Disaster Management Strategy for Cities of Geo-Techno-Environmental Risks in North Africa. A Case Study of Algeria, Integrated Disaster Risk Management: Megacity Vulnerability and Resilience, Laxenburg. www.iiasa.ac.at/Research/RMS/.../benouar.pdf

[11] Adelekan, I.O. (2011) Vulnerability Assessment of an Urban Flood in Nigeria: Abeokuta Flood 2007. Nat Hazards, 56, 215-231. http://dx.doi.org/10.1007/s11069-010-9564-z

[12] Parker, D. (1999) Flood. In: Ingleton, J., Ed., Natural Disaster Management, Leicester, Tudor Rose, 38-40.

[13] Water Meteological Organization and Global Water Partnership (2008) Urban Flood Risk Management. Associated Programme on Flood Management, Technical Document No. 1, Flood Management Tools Series. http://www.answers.com/topic/socioeconomic-status

[14] Kiunsi, R., Kassenga, G., Lupala, J., Malele, B., Uhinga, G. and Rugai, D. (2009) Mainstreaming Disaster Risk Reduction in Urban Planning in Tanzania. Auran Phase II, Project Final Report.

[15] Sakijege, T., Lupala, J. and Sheuya, S. (2012) Flooding, Flood Risks and Coping Strategies in Urban Informal Residential Areas: The Case of Keko Machungwa, Dar es Salaam, Tanzania. Jamba: Journal of Disaster Risk Studies, 4, 46-56.

[16] Kothari, C.R. (1993) Research Methodology, Methods and Techniques. US Johri for Wiley Eastern Limited. 
[17] Baradyana, J.S. and Ame, A. (2005) Quantitative Techniques for Business Decisions. Mkuki na Nyota, Dar es Salaam.

[18] Foster, S.S.D., Hirata, R., Gomes, D., D’Elia, M. and Paris, M. (2002) Groundwater Quality Protection: A Guide for Water Utilities, Municipal Authorities and Environment Agencies. World Bank, Washington DC. http://dx.doi.org/10.1596/0-8213-4951-1

[19] Jabeen, H., Johnson, C. and Allen, A. (2010) Built-In Resilience: Learning from Grassroots Coping Strategies for Climate Variability. Environment and Urbanization, 22, 415-443. http://dx.doi.org/10.1177/0956247810379937

[20] Haque, A.N., Grafakos, S. and Huijsman, M. (2012) Participatory Integrated Assessment of Flood Protection Measures for Climate Adaptation in Dhaka. Environment and Urbanization, 24, 197-213. http://dx.doi.org/10.1177/0956247811433538 
Scientific Research Publishing (SCIRP) is one of the largest Open Access journal publishers. It is currently publishing more than 200 open access, online, peer-reviewed journals covering a wide range of academic disciplines. SCIRP serves the worldwide academic communities and contributes to the progress and application of science with its publication.

Other selected journals from SCIRP are listed as below. Submit your manuscript to us via either submit@scirp.org or Online Submission Portal.
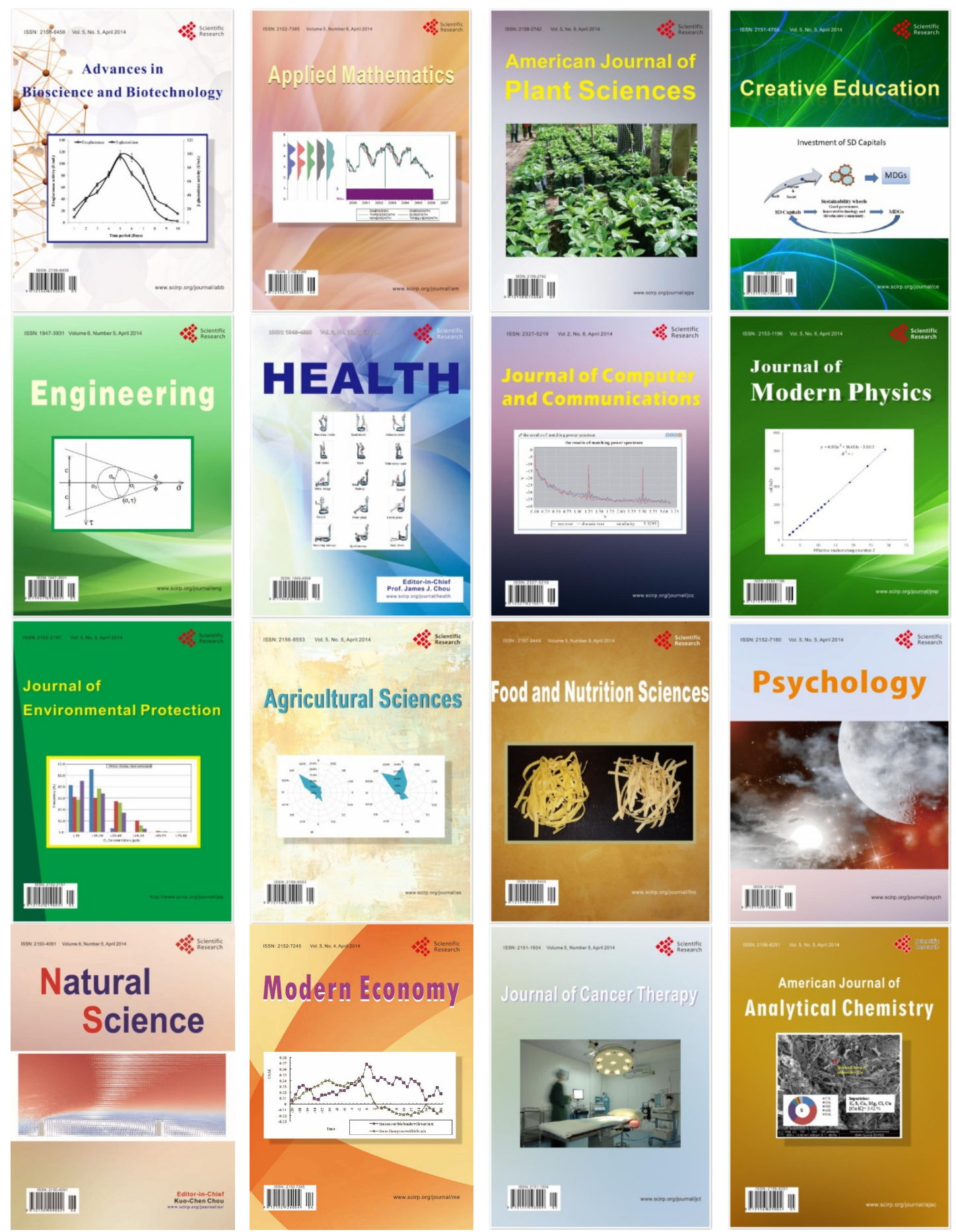